\title{
A krónikus magnéziumhiány jelentősége diabetes mellitusban*
}

\author{
Borbola József dr.
}

* A szerkesztőbizottság felkérésére készített kézirat

\begin{abstract}
Öszzefoglalás
Az elmült évtizedekben a civilizációs ártalmak következtében jelentösen csökkent az esszenciális mikronutriens magnézium napi bevitele. A felnött lakosság egyre növekvö részében krónikus, látens magnéziumhiány mutatható ki. A világszerte növekvö incidenciájú diabetes mellitusban (mindkét típusban) 13-47\%-ban magnéziumhiány tapasztalható, a vér magnéziumszintje közismerten igen alacsony lehet. A diabetes mellitus magnéziumpazarló krónikus anyagcsere-betegség, mivel mind a magnézium csökkent felszivódása, mind pedig - föként - a fokozott renalis magnéziumvesztés miatt jelentös magnéziumhiány alakulhat ki. A magnézium csökkent bevitele, a magnéziumhiány elösegíti a 2-es típusú diabetes mellitus kialakulását (inzulinrezisztencia alakul ki) és progresszióját, mig a magnéziumstátusz optimális kontrollja protektiv szerepet játszik nemcsak a 2-es típusú diabetes mellitus kialakulásában, késleltetésében, hanem a már kialakult szövődmények mérséklésében is. A krónikus magnéziumhiány diagnózisa a Magnézium Kutatási Társaság 2017-es ajánlása alapján három tényezö számbavételén alapszik: (1) klinikai tünetek (neuromuscularis hyperexcitabilitás), (2) a kórelözmény, betegségek, gyógyszeres kezelés áttekintése, (3) a szérum magnéziumszintjének meghatározása ( $\leq 0,70$ mmol/I). Az ajánlás szerint diabetes mellitusban napi $10-20 \mathrm{mmol}$ magnézium (240-480 mg), gyermekeknél $6 \mathrm{mg} / \mathrm{kg} / \mathrm{hap}$ bevitel javasolt. A kettös, aktivéletfontos hatóanyagot tartalmazó, kisérletesen és klinikailag is széles körüen vizsgált magnéziumorotát komplex biokémiai és élettani hatásai miatt elsóként javasolható diabetes mellitusban a krónikus magnéziumhiány kezelésére.
\end{abstract}

Kulcsszavak: magnézium, magnéziumhiány, diabetes mellitus, magnézium-orotát

\section{The importance of chronic magnesium deficiency in diabetes mellitus}

Summary: In the last decades the daily intake of the essential micronutrient magnesium is considerably decreased due to the civilized harms. Nowadays chronic latent magnesium deficiency can be revealed in the continually increasing part of the adult population on the western type of diet. In diabetes mellitus (in both types), which incidence is growing worldwide, magnesium deficiency can be demonstrated in $13-47 \%$, and the blood level of magnesium can be rather low in these patients. Diabetes mellitus is a magnesium-wasting chronic metabolic disease because not only the decreased absorption, but also the increased renal magnesium excretion. The magnesium deficiency promotes the development and progression of diabetes mellitus due to the insulin resistance induced by magnesium loss. On the other hand, the optimal control of the magnesium status plays a protective role not only in the development and slowing the progression of diabetes mellitus, but also in the reduction of the severity of diabetic complications. The recent recommendations of the Association of Magnesium Research (2017) are as follows: the diagnosis of the chronic magnesium-deficiency is based on three aspects: (1) clinical symptoms (neuromuscular hyperexcitability), (2) patient history (risk assessment of magnesium deficiency), (3) laboratory examination (blood magnesium level $\leq 0,70 \mathrm{mmol} / \mathrm{I}$ ). For magnesium therapy the guideline recommends daily oral supplementation with $240-480 \mathrm{mg}(10-20 \mathrm{mmol} / \mathrm{I})$, or in children $6 \mathrm{mg} / \mathrm{kg}$ body weight. For the first line of the treatment of chronic magnesium deficiency magnesium-orotate supplementation is suggested due to its complex biochemical and physiologic effects. magnesium-orotate containing a double, biologically active, vitally important substance which has been widely studied both experimentally and clinically. 
Key words: magnesium, magnesium deficiency, diabetes mellitus, magnesium orotate

DIABETOLOGIA HUNGARICA 26 (№5) 291-300. 2018. december

DOI: $10.24121 / \mathrm{dh} .2018 .18$

\section{Rövidítések}

EGF: epidermal growth factor; HOMA-IR: Homeostatikus Modell az Inzulinrezisztencia Megállapítására (Homeostatic Model Assessment for Insulin Resistance); NMDA: N-metil-D-aszpartát; PPI: protonpumpa-inhibitor; TRPM6/TRPM7: tranziens receptor potenciál melasztatin 6/7 típus (trans-receptor potential melastatine type 6 and 7)

$\mathrm{J}$ óllehet a magnézium (a név a görög magnészia szóból ered) gyógyító hatását már 400 éve megfigyelte egy farmer a kútjaiból magnéziumsós vizet ivó állatain Epsomban („epsomi só”), azonban még hosszú idő eltelt addig, amíg a múlt század elején (1926) kiderült, hogy a magnéziumionok vitális fontosságúak az emberi szervezet homeostasisának fenntartásában, szabályozásában. Manapság már jól ismert a magnéziumbevitel, -adás jótékony hatása, fontossága számos cardiovascularis (atherosclerosis, szívritmuszavarok, hirtelen szívhalál [aritmia], hypertonia, coronariabetegség, vasospasmus, stroke, krónikus systolés szívelégtelenség stb.) és extracardialis (2-es típusú diabetes mellitus, metabolikus szindróma, preeclampsia, premenstruációs szindróma, migrén, a neuromuscularis görcskészség fokozódása, véralvadás, lipidek, osteoporosis stb.) megbetegedés prevenciójában és kezelésében. ${ }^{1,2,3,4,5,6}$

Guasch-Ferré és mtsai 2014-ben közölték a magnéziummal kapcsolatos mérföldkő PREDIMED (Prevención con Dieta Mediterránea - Prevenció Mediterrán Diétával) tanulmányt. Eszerint a magnézium napi bevitele, valamint a cardiovascularis, daganatos és az összmortalitás között is fordított összefüggés áll fenn: a legmagasabb magnéziumbevitelű személyek

\section{1. táblázat. A magnézium orvosi történetének föbb mérföldkövei}

Epsom, 1618 - „epsomi só” $\left(\mathrm{MgSO}_{4} \times 7 \mathrm{H}_{2} \mathrm{O}\right)$

R. Willstäter, 1915 - a magnézium a klorofil koordinációs ionja W. G. Denis, 1920 - a vérben magnézium található

J. Leroy, 1926 - a magnézium esszenciális az élethez

L. Zwilinger, 1935 - magnézium antiaritmiás hatása

R. J. M. Bindels, 2005 - magnéziumtranszporterek felfedezése

M. Guasch-Ferré és mtsai, 2014 - a magnéziumbevitel fordított összefüggésben van a felnőttek halálozásával összhalálozási rizikója 34\%-kal volt kisebb az alacsony magnéziumbevitelű egyénekhez képest.

A magnéziumbevitel kedvező, jótékony hatásainak a hátterében a magnéziumionok komplex élettani (celluláris fiziológia, ion- és metabolittranszport, a vascularis tónus csökkentése, endothelfunkciómodulátor, antistressz elektrolit stb.) és biokémiai hatásai állnak. A cardiovasoprotectiv, káliumot védő magnéziumot a természet fiziológiás kalciumblokkolójaként, kalciumantagonistaként tartják számon (NMDA-receptor-gátló). A magnézium biokémiai hatásspektruma is rendkívül széles. Jelentősége abban áll, hogy a glukóz-, protein- és a zsíranyagcserében szereplő mintegy 600 enzim kofaktora, mintegy 200 enzimnek pedig aktivátora, aktív konformációjuk stabilizátora. Fontos szerepet játszik az energiaátvitelben, a mitokondriális ATP-szintézisben, az ATP foszfáttranszferében, a DNS- és RNS-szintézisben, a nukleotid kötések stabilitásában, így kulcsfontosságú a genomikus és genetikai stabilitás megőrzésében. A glikolízis enzimei és az inzulinjelátvitelben szereplő tirozin-kináz enzim modulációja miatt fontos szerepe van a T2DM kialakulásának gátlásában. A telomeráz enzim szabályozása révén közvetve az öregedés folyamatában is részt vesz. ${ }^{1,2,3,4,5}$ A magnézium komplex hatásai rendkívül szerteágazóak (pl. a vér- és az intracelluláris magnéziumszint oszcillációja, a sejt-,óra” szabályozása), sok esetben még feltáratlanok. ${ }^{1,2,4,5}$

A sokáig elfelejtett ionként aposztrofált, hosszú ideig méltánytalanul alulbecsült esszenciális mikronutriens, a magnézium az intenzív alapkutatásoknak köszönhetően (szövetspecifikus magnéziumtranszporterek felfedezése, NMDA-receptorgátlás, tirozinkináz aktivitás modulációja stb.) az elmúlt évtizedben az érdeklődés előterébe került. ${ }^{1,2,45}$ Ugyanakkor a magnéziumbevitellel, vérszinttel, kezeléssel kapcsolatos 


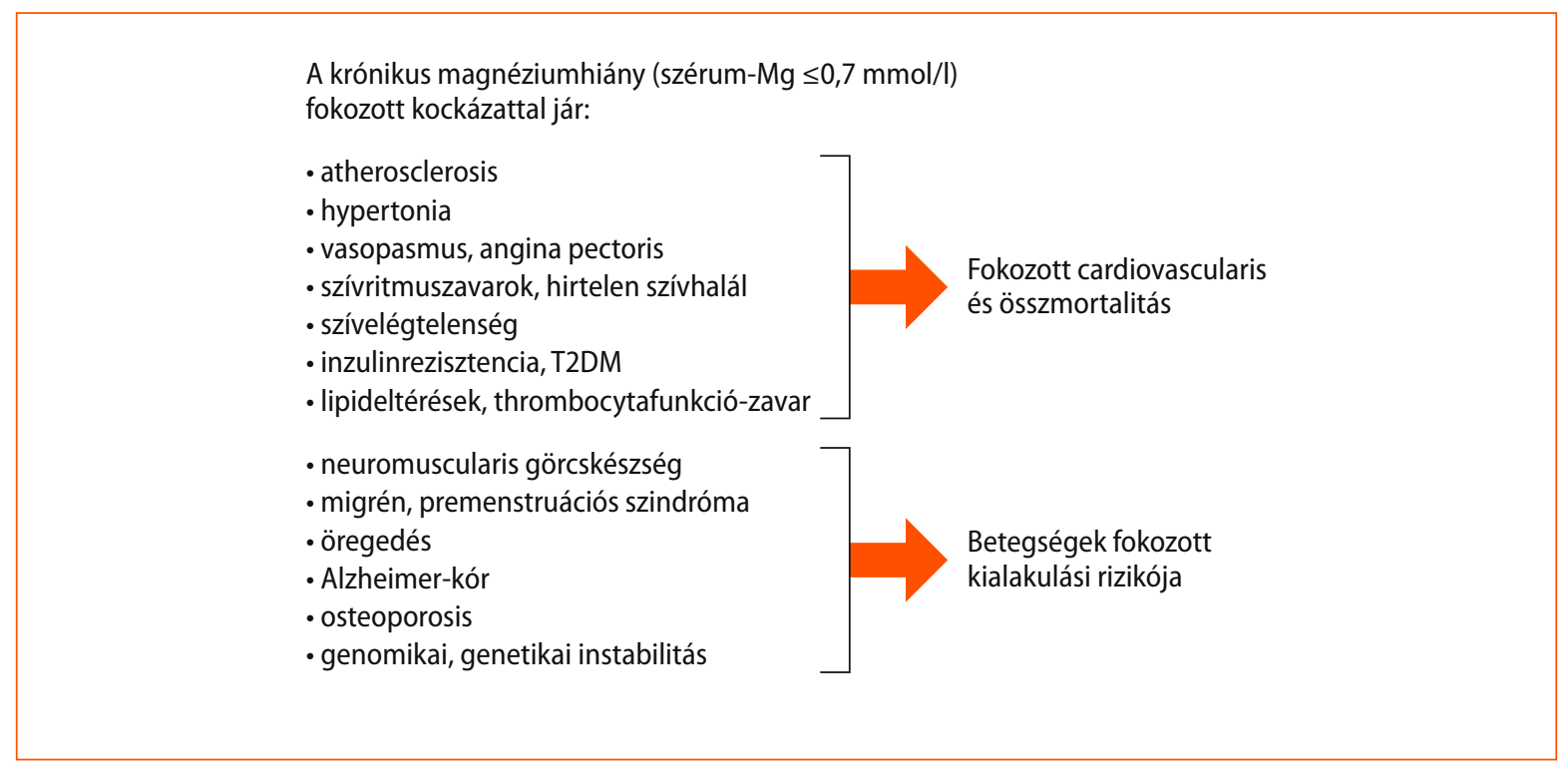

1. ábra. A krónikus magnéziumhiány számos cardiovascularis betegség és az összmortalitás fokozott kockázatát jelzi. Emellett néhány extracardialis kórkép fokozott kialakulási rizikójára is hajlamosit

epidemiológiai, klinikai kutatások eredményei is rendkívül sok új ismeretet, adatot szolgáltattak. ${ }^{1,2,5}$ A magnéziumkutatás orvosi történetének fontos mérföldköveit az 1. táblázat foglalja össze.

Mai ismereteink szerint a krónikus magnéziumhiány (szérum magnéziumszint $\leq 0,70 \mathrm{mmol} / \mathrm{l}$ ) együtt jár számos preklinikai állapot kialakulásával és a rossz klinikai kimenetel fokozott kockázatával. Ezen felül a magnéziumhiány lehet az egyik patofiziológiai kapocs, amely segít feltárni a gyulladásos és oxidatív stresszel járó biológiai állapotok kölcsönhatásait. Nemcsak pl. az öregedés folyamatában, hanem sok, az életkorral összefüggésbe hozható betegséggel is (1. ábra). ${ }^{1,2,4,5,8,9}$

A diabetes világszerte jelentősen növekvő előfordulási gyakorisága, a micro- és macrovascularis szövődmények kialakulása fontos közegészségügyi problémát, nagy gazdasági terhet jelent az egészségügyi ellátó rendszerekre, különösen a fejlődő országokban. DM-ben jelentős magnéziumhiány alakulhat ki, fóként az ion felszívódásának csökkenése, valamint a fokozott kiválasztás miatt. A magnéziumhiánynak kóroki jelentőséget tulajdonítanak nemcsak a T2DM kialakulásában, hanem a diabeteses komplikációk kifejlődésében is. ${ }^{1,2,59}$
A jelen közlemény célja, hogy a krónikus magnéziumhiány kialakulását, okait, kezelését, valamint a rossz klinikai kimenetelt előre jelző mikronutriens magnézium hiányának jelentőségét áttekintse DM-ben.

\section{A magnéziumhiány mint civilizációs ártalom}

Az emberi szervezet magnéziumszükségletét, igényét a természet nem élő elemeiből származó, ún. primer magnéziumforrások (kőzetek, ásványok, termőtalaj, ivóvíz stb.), valamint az ezek anyagáramlási folyamatait felhasználó növény- és állatvilág, döntően a táplálkozási lánc (étkezés: természetes és iparilag feldolgozott élelmiszerek és az ivás: ivóvíz, ásványvíz, üdítőitalok, alkoholos italok stb.) biztosítja. ${ }^{6}$ Az utóbbi két-három emberöltőben a humán természetes magnéziumforrások a civilizációs ártalmak következtében kiapadóban vannak. A kiterjedt műtrágyázás a termőföld, következésképpen a termelt növények, zöldségek, gyümölcsök magnéziumtartalmának a jelentős csökkenéséhez vezetett. A természetes tápanyagok ipari, gyári feldolgozása során magnéziumtartalmuk további nagy részét, $60-80 \%$-át elveszítik. Emiatt a természetes magnéziumbevitel jelentősen apadó, csökkenő tendenciát mutat. ${ }^{1,2,4,5,6}$ Európai felmérés szerint a nyugati típusú étkezésen, diétán lévő lakosság 
napi magnéziumbevitele 30-50\%-kal csökkent az ajánláshoz képest. ${ }^{6}$

A csökkenő magnéziumbevitel mellett a diabetes mellitus (T2DM), alkoholizáció elterjedése, a nettó endogén savtermelést fokozó étkezés, az öregedő lakosság számos társbetegsége, a tartós, sokszor indokolatlan gyógyszerszedés (pl. protonpumpagátlók [PPI-k]) jelentősen csökkentheti a szervezet magnéziumszintjét. ${ }^{1,2,5,6,8,9,10}$

Az ajánlott hazai napi magnéziumbevitel a humán táplálkozásban átlagos testsúly esetén 5-6 $\mathrm{mg} / \mathrm{kg}$. A magnéziumigény azonban sok esetben ennél sokkal nagyobb, jelentősen megnő pl. sok stresszhatás, versenysport, idős életkor, terhesség, szoptatás, betegségek stb. eseteiben., ${ }^{4,6}$

\section{A magnéziumhiány okai}

A magnéziumhiány klinikai szindróma, ami a magnézium metabolizmusának látens vagy manifeszt (klinikai tünetekkel) zavarát jelenti. ${ }^{3,4,5,11}$

Felmérések szerint a magnéziumhiány gyakoriságát 10-20\%-ra teszik kórházi betegek körében. Intenzív osztályon előfordulása nagyobb (50-60\%), diabeteses betegekben 13-47\%, alkoholistáknál pedig 30-80\%. ${ }^{12}$ Ugyancsak gyakori malabszorpcióban, osteoporosisban. A hypomagnesaemia $(\leq 0,70$ $\mathrm{mmo} / \mathrm{l})$ 40\%-ban hypokalaemiával, 22-32\%-ban pedig hypocalcaemiával társul (terápiarezisztens hypokalaemia, illetve hypocalcaemia). ${ }^{1,2,5,12}$ A magnéziumhiány oka lehet

1. veleszületett, primer génmutációk (TRPM6/ TRPM7), (tranziens receptor potenciál melastatin 6-os, illetve 7-es típus anomáliái), ezek általában már csecsemőkorban jelentkeznek és ritkák;

2. szekunder vagy szerzett hypomagnesaemia (pl. a napi magnéziumbevitel csökkenése és/vagy magnéziumvesztés [vese, széklet] miatt). A táplálkozással/gyógyszerekkel bevitt magnézium felszívódásában, hasznosulásában tapasztalható genetikai változékonyság miatt a magnéziumhiányra mutatkozó érzékenység nagy egyéni variábilitást mutat. ${ }^{1,2,5,12}$

A szerzett magnéziumhiány enyhébb-súlyosabb állapotainak kialakulása általában táplálkozási, magnéziumbeviteli és/vagy felszívódási zavarokra (betegség vagy gyógyszermellékhatás), veseeredetű okokra (betegség vagy gyógyszermellékhatás), valamint endokrin és anyagcserezavarra (vagy ezek kombinációira) vezethetők vissza. ${ }^{12}$ $\mathrm{Az}$ egyes okok részletes felsorolását a 2. táblázat foglalja össze.

A magnéziumhiány az ion-homeosztázisnak a modern élettel, a sok stresszel, az egészségtelen, ún. nyugati típusú táplálkozással együtt járó gyakori, elterjedt zavara. Leggyakrabban elégtelen magnéziumbevitel (zsíros, sós ételek, szénsavas,

\section{2. táblázat. A magnéziumhiány föbb okai}

\begin{tabular}{|c|c|c|c|c|}
\hline Táplálkozási okok & Felszívódási zavarok & Renalis okok & $\begin{array}{l}\text { Endokrin diszfunkciók, } \\
\text { anyagcserezavarok }\end{array}$ & Fokozott szükséglet \\
\hline $\begin{array}{l}\text { • Csökkent, elégtelen } \\
\text { magnéziumbevitel } \\
\text { az élelmiszerek } \\
\text { ipari feldolgozása, a } \\
\text { termőföld mütrágyázása } \\
\text { következtében } \\
\text { • Fehérjehiányos } \\
\text { táplálkozás } \\
\text { - Alkoholizmus (fokozott } \\
\text { renalis kiválasztás) } \\
\text { • Foszfáttartalmú } \\
\text { üdítőitalok }\end{array}$ & $\begin{array}{l}\text { • Malabszorpció, } \\
\text { folyadék-, } \\
\text { elektrolitveszteséggel } \\
\text { járó gastrointestinalis } \\
\text { betegségek (pl. } \\
\text { vékonybél-rezekció } \\
\text { utáni állapotok) } \\
\text { - Idült hasmenések, } \\
\text { enteropathiák } \\
\text { - Gyógyszer- } \\
\text { mellékhatások: } \\
\text { protonpumpagátlók } \\
\text { (PPI-k) rendszeres } \\
\text { szedése (reverzíbilis), } \\
\text { hashajtók rendszeres } \\
\text { használata }\end{array}$ & $\begin{array}{l}\text { - Vesebetegségek (renalis } \\
\text { tubularis acidózis, } \\
\text { krónikus pyelonephritis, } \\
\text { glomerulonephritis, } \\
\text { csökkent } \\
\text { kationreabszorpcióval } \\
\text { járó vesemúködési } \\
\text { zavarok stb.) } \\
\text { - A nettó endogén } \\
\text { savtermelést } \\
\text { fokozó táplálkozás } \\
\text { következtében a } \\
\text { magnézium renalis } \\
\text { kiválasztása fokozódik } \\
\text { - Gyógyszermellékhatások }\end{array}$ & $\begin{array}{l}\text { - Primer, szekunder } \\
\text { hyperaldosterinismus } \\
\text { - Hyperthyreosis, } \\
\text { hyperparathyreosis } \\
\text { - Onkológiai kórképek } \\
\text { okozta hypercalcaemia } \\
\text { - Diabetes mellitus, } \\
\text { metabolikus szindróma }\end{array}$ & $\begin{array}{l}\text { - Terhesség, szoptatás } \\
\text { - Versenysport, erős fizikai } \\
\text { munka }\end{array}$ \\
\hline
\end{tabular}




\section{3. táblázat. Gyógyszerek okozta magnéziumvesztés}

\begin{tabular}{|c|c|}
\hline Gyógyszercsoport & Mechanizmus \\
\hline Aminoglycosidok (gentamycin, tobramycin, amikacin) & Fokozott renalis magnéziumvesztés, hyperaldosterinismus \\
\hline Antimikrobiális szerek (pentamidin) & Fokozott renalis magnéziumvesztés \\
\hline Antivirális szerek (foscarnet) & Nefrotoxicitás, fokozott renalis magnéziumvesztés \\
\hline Béta-adrenerg agonisták (fenoterol, salbutamol, theophyllin) & Fokozott renalis magnéziumkiválasztás metabolikus zavar \\
\hline Bifoszfonátok (pamidronat, alendronat) & Fokozott renalis magnéziumkiválasztás \\
\hline Digitalis-glikozidok & Csökkenti a magnézium renalis reabszorpcióját \\
\hline Hashajtók & Fokozott magnéziumvesztés \\
\hline Diuretikumok (hydrochlorothiasid, furosemid, etakrinsav stb.) & Fokozott renalis magnéziumvesztés, hyperaldosterinismus \\
\hline $\begin{array}{l}\text { Kemoterápiás szerek (amsucrin, cisplatin, carboplatin, } \\
\text { cetuximab) }\end{array}$ & $\begin{array}{l}\text { Nephrotoxicitás, cisplatin akkumuláció a vesekéregben, fokozott renalis } \\
\text { magnéziumvesztés }\end{array}$ \\
\hline Immunszuppresszív szerek (cyclosporin, sirolimus) & 2-3× fokozott renalis magnéziumkiválasztás (magnesium-wasting) \\
\hline Kacs diuretikumok (furosemid) & Fokozott renalis magnéziumvesztés hyperaldosterinismus \\
\hline Monoclonalis antitestek (cetuximab, panitumumab) & $\begin{array}{l}\text { EGFR-blokád, a nephronban gátolja a magnézium aktív transzportját } \\
\text { (magnesium-wasting) }\end{array}$ \\
\hline Polién gombaellenes szerek (amphotericin B) & Nefrotoxicitás \\
\hline Protonpumpagátlók & Az aktív magnéziumabszorpció elvesztése a TRPM6 és 7 receptorokon \\
\hline
\end{tabular}

foszfáttartalmú üdítőitalok, kávé, tea, energiaitalok túlzott fogyasztása) és/vagy excesszív magnéziumvesztés okozza, különösen, ha rendszeres alkoholfogyasztás, diabetes mellitus (mindkettőben fokozódik a renalis magnéziumvesztés), gyógyszermellékhatások (pl. PPI-k huzamos szedése, diuretikum-kezelés) is társulnak az előzőekhez. Magnéziumhiányos állapot gyakran kialakul a vékonybeleket érintő gastrointestinalis betegségekben (krónikus hasmenés, colitis ulcerosa, malabszorpció, Crohn-betegség, laktózintolerancia, coeliakia stb.). Hypomagnesiaemiát okozhatnak posztoperatív állapotok (vékonybél-reszekció, ún. metabolikus mủtétek stb.), szondatáplálás, magnéziummentes iv. folyadékterápia, abdominális röntgenbesugárzás, onkoterápia (radiációs enteritis) is. A magnéziumveszteséget okozó főbb gyógyszercsoportokat a következő, 3. táblázat foglalja össze. 1,2,3,5,12 Mintegy 50 gyógyszer okozhat magnéziumhiányt.

A leggyakoribb szimptomatikus magnéziumhiány a szívelégtelenség diuretikus kezelése, a PPI gyógyszerek tartós alkalmazása során, valamint diabetesben, idült alkoholizmusban szokott előfordulni. Az EGF-receptor-gátlók akár életveszélyes mértékű magnéziumvesztést idézhetnek elő. Súlyos hypomagnesaemia általában $\leq 0,50 \mathrm{mmol} / \mathrm{l}$ vérszint mellett fordul elő, amikor iv. magnézium infúziós kezelésre is sor kerülhet. ${ }^{12}$

\section{A krónikus magnéziumhiány diagnózisa}

$\mathrm{Az}$ egész test főként intracelluláris magnéziummetabolizmusát feltáró, egyszerű, gyors, megbízható klinikai noninvazív teszt még várat magára. A Magnézium Kutatási Társaság által elfogadott 2017-es javaslat szerint ${ }^{11}$ a krónikus, látens vagy manifeszt magnéziumhiány diagnózisa három tényező (4. táblázat) számbavételén alapszik:

1. klinikai tünetek (legfontosabb a neuromuscularis hyperexcitabilitás),

2. az ún. magnézium-rizikófaktorok, a kórelőzmény áttekintése (pl. az anamnézisben

\section{4. táblázat. A krónikus magnéziumhiány diagnózi- sa a Magnézium Kutatási Társaság javaslata (2017) alapján}

\begin{tabular}{|l|}
\hline \multicolumn{1}{|c|}{ 1. Klinikai tünetek } \\
\hline - neuromuscularis hyperexcitabilitás \\
\hline \multicolumn{1}{|c|}{ 2. Rizikófaktorok - anamnézis } \\
\hline $\begin{array}{l}\text { - diabetes mellitus } \\
\text { - jelentősebb, rendszeres alkoholizálás } \\
\text { - hypertonia, szívelégtelenség, coronaria-betegség } \\
\text { - malabszorpciós szindróma } \\
\text { - bizonyos gyógyszerek (PPI, SSRI, diureticumok, laxativumok } \\
\text { stb.) }\end{array}$ \\
\hline 3. Szérummagnézium-szint \\
\hline$\cdot \leq 0,70 \mathrm{mmol} / \mathrm{I}$ \\
\hline
\end{tabular}


cukorbetegség, rendszeres alkoholizálás, bizonyos gyógyszerek [pl. PPI-k, diuretikumok stb.] szedése),

3. szérum magnéziumszint meghatározása $(\leq 0,70 \mathrm{mmol} / \mathrm{l})$.

Miután az oralis magnéziumadás mennyisége és a magnézium vérszintje között jó dózis-hatás görbét tapasztaltak, ${ }^{12}$ ezért a magnézium vérszintjét megfelelő biomarkernek javasolják a szervezet magnéziumellátottságának a megítélésére. A szérum magnéziumszint ugyan nem utal a teljes test magnéziumtartalmára, de az alacsonyabb vérszint majdnem mindig magnéziumhiányra utal. $\mathrm{Az}$ amerikai NHANES (National Health and Nutrition Examination Survey - Nemzeti Egészség és Táplálkozási Vizsgálat) vizsgálat felmérése szerint a felnőttek normális magnéziumvérszintjének referenciatartománya 0,75-0,95 (átlagosan: $0,85) \mathrm{mmol} / \mathrm{l}$. Egy európai tanulmány ${ }^{13}$ megállapítása szerint $0,70 \mathrm{mmo} / 1$ magnéziumvérszint esetén a 90\%-ban klinikai magnéziumhiány állapítható meg, 0,75 mmol/l-nél csak 50\%-ban, 0,80 mmol/l-nél 10\%-ban, míg 0,90 mol/l-nél pedig már csak 1\%-ban tapasztaltak klinikai magnéziumhiányt. Manapság a szérum magnéziumszintjét már majdnem minden laboratóriumban rutinszerủen meghatározzák (bár nem mindenhol azonos módszerrel). Miután a szérum magnéziumszintje a ma elfogadott álláspont szerint a cardiovascularis megbetegedések előrejelzője, rizikófaktora, ezért fontos laboratóriumi paraméter. A bonyolultabb, nehézkesebb napi magnéziumbeviteli számítás, a vizeletben mért magnéziumürítés helyett világszerte a három pontból álló diagnosztikát javasolják. ${ }^{11}$ Sőt, közegészségügyi jelentősége miatt a vér normális magnéziumszintje alsó referenciaértékének megemelését tanácsolják $0,70 \mathrm{mmol} / \mathrm{l}-$ ről 0,80 mmol/l-re. ${ }^{14}$ Megfelelő magnézium-ellátottság mellett számítások szerint a szívizominfarktus okozta halálozás évente nőknél 23/100000-rel, míg férfiaknál 65/100000-rel csökkenthető lenne. ${ }^{10}$ Magnéziumhiányra utal, ha a magnéziumürítés a vizeletben $\leq 80 \mathrm{mg} / 24$ óra. ${ }^{12}$ A fokozódó, általános magnéziumbeviteli zavarra utal az is, hogy az elmúlt évtizedekben a vörösvértestek magnéziumszintjének (normális érték: 1,65-2,65 mmol/l) fokozatos csökkenését tapasztalták. ${ }^{1,2,5,12}$

$\mathrm{Az}$ elmúlt évtizedekben a magnéziumbevitel csökkenésével párhuzamosan a kalciumbevitel folyamatosan emelkedett a nyugati világban, ami magas kalcium-/magnéziumbeviteli arányt $(\geq 2,6)$ (normális érték: 1,7-2,6) eredményezett. Szakértők szerint ez a magas arány genetikai polimorfizmus révén növelheti a gastrointestinalis neoplasia és az összhalálozás mértékét. ${ }^{2}$ A magnézium jótékony élettani/biokémiai hatása csak a normális 1,7-2,6 arány mellett tud érvényesülni. Ettől függetlenül a szérum $\mathrm{Mg}: \mathrm{Ca}$ arányát (normális érték: 0,4; túl alacsony: 0,28-0,36) is vizsgálták. Ujabban ezt az arányt a magnéziumszint és -metabolizmus sokkal érzékenyebb és praktikusabb indikátorának tartják, mint a szérum magnéziumszintet. ${ }^{1,2,5,12}$

A magnéziumhiány korai klinikai jelei aspecifikusak: étvágytalanság, alvászavar, hányinger, hányás, gyengeség, erőtlenség, fáradtságérzés. A magnéziumhiány rosszabbodása esetén az előzőekhez zsibbadás, bizsergés, izomrángások (tic), lábikra-, vádligörcsök, izomgörcsök, szívritmuszavarok, tetániás epizódok, személyiség-változások, apátia, érspazmusok társulhatnak. DM-ben a hyperreflexia a polyneuropathia miatt kevésbé lehet kifejezett. $^{12}$

Gambling és mtsai szerint a magnéziumhiány tünetei négy csoportba sorolhatók: ${ }^{12}$

1. Neuromuscularis hyperexcitabilitás.

2. Neuropszichiátriai: apátia, depresszió, szorongás, hallucináció, akár delírium is.

3. Cardiovascularis: pitvari és kamrai extrasystolék megjelenése, a PQ, QT távolság megnyúlása, a T-hullám hasadtsága, pitvarfibrillációs epizódok (aszimptomatikus is lehet) megjelenése, coronaria-vasospasmuskészség, fokozott digitáliszérzékenység, „torsades de pointes" típusú, polimorf, nem tartós vagy tartós kamrai tachycardiás epizódok előfordulása, a hypertonia rosszabbodása. ${ }^{3}$ A krónikus magnéziumhiány az atherosclerosis, a coronaria-betegség kialakulásának egyik rizikótényezője is. ${ }^{3}$

4. Metabolikus: refrakter hypokalaemia, hypocalcaemia kialakulása, amely csak magnézium adása után rendeződik. ${ }^{12}$

A szubklinikus, látens magnéziumhiány sokszor nehezen ismerhető fel. A mindennapos orvosi gyakorlatban azonban közegészségügyi jelentősége (a cardiovascularis halálozás fokozódása) miatt is nagy hangsúlyt kell fordítani a magnéziumhiány 
kimutatására, megelőzésére és kezelésére egyaránt. ${ }^{1,2,4,5,9,15}$

\section{Magnézium, metabolikus szindróma, diabetes mellitus}

Jól ismert, hogy a magnéziumhiány okai között gyakran szerepel a diabetes mindkét típusa. A cukorbetegekben gyakori a hypomagnesiaemia, nem ritkán igen alacsony érték $(\approx 0,50 \mathrm{mmol} / \mathrm{l})$ is előfordul, akár aszimptomatikus formában. ${ }^{12}$ Ennek hátterében az elégtelen magnéziumellátottság, főként a fokozott renalis magnéziumvesztés, a magnéziumionok facilitált diffúziójának, felszívódásának csökkenése, az autonóm neuropathia kialakulásával járó krónikus hasmenés játszik szerepet. ${ }^{5,12}$ Emellett a magnéziumürítést fokozó gyógyszerhasználat (pl. diuretikumok), a magnézium felszívódását csökkentő szerek (pl. protonpumpagátlók), társuló betegségek (pl. enteropathiák), alkoholizmus is súlyosbíthatják a fontos mikronutriens hiányának kialakulását. ${ }^{1,2,5,15,16}$ A hypomagnesiaemia hozzájárulhat a T2DM kialakulásához, mivel fokozza az inzulinrezisztenciát. ${ }^{17}$

Az inzulinreceptorok a tirozin-kináz receptorok családjához tartoznak, a kináz funkció viszont 2 magnéziumion kötődésétől függ. ${ }^{1,2,5} \mathrm{Az}$ inzulinreceptor aktiválódásakor komplex intracelluláris jelátviteli kaszkád indul be a receptorszubsztrát proteinek közreműködésével: hypomagnesaemia esetén az inzulinreceptorok csökkent aktivációja csökkent jelátvitelhez vezet, ami hozzájárul többek között az inzulinrezisztencia kialakulásához. A magnéziumionok befolyásolják a foszforiláz D kináz működését is, amely felszabadítja a glukóz-1-foszfátot a glikogénből. Ezenfelül a magnéziumionok közvetlenül befolyásolják a glukóztranszporter protein (GLUT-4) aktivitását is, amely segít szabályozni a glukóz transzlokációját a sejtbe. ${ }^{1,2,5} \mathrm{Az}$ inzulin viszont szabályozza az intracelluláris magnéziumszintet a $\mathrm{Na}^{+} / \mathrm{Mg}^{++}$-exchanger aktiválásával, és ugyancsak inzulin szükséges a magnéziumionok intracelluláris transzportjához is, így a magnéziumionok és az inzulin között szoros a kölcsönhatás. Ezek a vizsgálatok arra utalnak, hogy a magnéziumban gazdag táplálkozás segíthet csökkenteni a T2DM kialakulásának rizikóját. ${ }^{1,2,5,16,17}$

A NHANES I. tanulmány 18 éves utánkövetéses adatai szerint minél alacsonyabb a vér magnéziumszintje, annál nagyobb a T2DM kialakulásának kockázata, <0,80 mmol/lnél már 1,5-szeres. ${ }^{18}$ Más vizsgálatokban ${ }^{19,20} 0,82-1,03$ mmol/1 magnéziumvérszint mellett találták a legjobb glykaemiás kontrollt és a vesefunkció legkisebb arányú csökkenését.

Az utóbbi évek epidemiológiai vizsgálatai kimutatták, hogy a magnéziumbevitel fordított összefüggésben van a T2DM kifejlődésével. ${ }^{1,2,5,11,17,21,22}$ Ezek közül néhány vizsgálat impresszív hatást mutatott a $\mathrm{HbA}_{1 \mathrm{c}}$-szint és az éhomi glukózszint csökkenésére, ${ }^{21,22}$ más tanulmányok viszont nem találtak számottevő javulást a glykaemiás kontrollban. ${ }^{21,22}$ T2DM-ben a magnéziumhiány jól korrelál a betegség időtartamával és az albuminürítés mértékével is. ${ }^{1,2,5} 85060$ egészséges nő 18 éves utánkövetése során azt is kimutatták, hogy minél nagyobb a napi magnéziumbevitel (222-373 mg/nap), annál nagyobb a magnézium T2DM-rizikót csökkentő hatása (12-34\%). ${ }^{15}$ Kim és mtsai azt közölték, hogy 200 mg-ról 400 mg/nap-ra emelve a magnéziumbevitelt, közel $50 \%$-kal csökken a T2DM rizikója. ${ }^{17}$ A magnéziumhiány nemcsak kockázati tényezője az inzulinrezisztencia és a T2DM kialakulásának, hanem maga a diabetes is az egyik leggyakoribb oka a magnéziumhiánynak. . $2,5,11,17,21,22^{2}$

További hét prospektív vizsgálat (1966-2007 között, 286668 résztvevő) metaanalízise megerősítette a per os magnéziumbevitel és a T2DM kialakulási rizikójának az összefüggését: 100 mg magnéziumbevitel a relatív kialakulási rizikót 15\%kal csökkentette. ${ }^{1,25,21}$ Egy másik amerikai prospektív tanulmányban fiatal felnőttekben (4479 résztvevő, 18-30 évesek) vizsgálták a hosszú távú magnéziumbevitel és az inzulinrezisztencia összefüggését. Multivariáns analízis azt igazolta, hogy a legmagasabb magnéziumbevitelűek csoportjában 47\%-kal (0,53, 95\%-os CI: 0,32-0,86; p<0,001) volt kisebb a T2DM kialakulása a legkevesebb magnéziumot szedők csoportjához képest. Ugyanebben a vizsgálatban a magnéziumbevitel fordítva és szignifikánsan függött össze az inzulinrezisztencia-index paraméterével (HOMA-IR). ${ }^{1,2,5,17}$ Egy 13 prospektív vizsgálatot felölelő metaanalízis (536318 résztvevő) is megerősítette a magnéziumbevitel és a T2DM kialakulása közötti szignifikáns fordított összefüggést. ${ }^{23}$ Újabb vizsgálatok arra utalnak, hogy a javasolt napi magnéziumbevitel $(350 \mathrm{mg} / \mathrm{nap})$ jelentősen csökkentette a prediabetes progressziójának a rizikóját a T2DM kialakulására. ${ }^{5}$ Úgy tűnik, hogy a magasabb magnéziumbevitel különösen kedvező lehet olyan középkorú egyéneknél, akiknél familiárisan nagyobb az esély a T2DM kialakulására. ${ }^{5}$

A magnéziumbevitel szerepét tanulmányozták túlsúlyos, normomagnesiaemiás egyénekben is, akiknek 
inzulinrezisztenciájuk volt, de T2DM még nem alakult ki. ${ }^{5,24,25,26}$ A 6 hónapos magnéziumadagolás a placebóhoz képest jelentősen javította az éhomi glukóz és az inzulin vérszintjét. ${ }^{27}$

Guerrero-Romero és mtsai tízéves prospektív, utánkövetéses vizsgálatukban megerősítették a hypomagnesaemia szerepét az IFG, IGT, IFG+IGT és a T2DM kialakulási rizikójának a vonatkozásában is. ${ }^{25}$ Ugyanez a munkacsoport kettős-vak, placebokontrollált vizsgálatukban $2,5 \mathrm{~g} \mathrm{MgCl}_{2}$ /nap adásával jelentős javulást értek el prediabeteses betegekben az éhomi vércukor és az inzulinrezisztencia paramétereiben. ${ }^{26}$ Ezek a vizsgálatok arra hívják fel a figyelmet, hogy a magnéziumstátusz korai optimalizációja megelőzheti az inzulinrezisztencia, illetve a következményes T2DM kialakulását. ${ }^{1,2,5,11,21,22,24,28}$

Az előzőekben leírtak alapján az a következtetés is levonható, hogy a diabetes diagnózisa sokszor egyenlő a magnéziumhiánnyal, a magnéziumhiány viszont fokozza a betegség progresszióját, circulus vitiosust okozva. Kimutatták, hogy a kiegyensúlyozott magnéziumstátusz együtt járt a micro- és macrovascularis szövődmények kialakulásának késleltetésével, azok csökkentebb rizikójával.,2,5,11

A Magnézium Kutatási Társaság legutóbbi, 2017-es irányelvei szerint a magnéziumszupplementáció jótékony hatása az inzulinszenzitizáló, kalcium-antagonista, stressz-szabályozó és endotheliumstabilizáló cardiovasoprotectiv tulajdonságain alapszik. ${ }^{11}$ Ezért a diabeteses betegeknek napi 240-480 mg (10-20 mmol) magnéziumbevitelt javasolnak, gyermekek esetén napi $6 \mathrm{mg} / \mathrm{kg}$ adagot. ${ }^{11}$ A legtöbb esetben folyamatos, állandó magnéziumkezelés célszerű. A nagyobb adagban történő magnéziumbevitelnek, kezelésnek komoly mellékhatása nincsen. Másod-harmadfokú atrioventricularis blokk, veseelégtelenség (eGFR $<30 \mathrm{ml} / \mathrm{min}$ ), myasthenia gravis a magnéziumadás ellenjavallatát jelenti. ${ }^{12}$ Ugyanakkor a magnéziumkezelés jól kombinálható az összes antidiabetikus és antihypertensiv gyógyszerrel. A magnéziumhiány felmérése minden DM-es, inzulinrezisztenciás és metabolikus szindrómás betegen szükséges. ${ }^{11}$

\section{A krónikus magnéziumhiány kezelése}

A magnéziumhiány diagnózisának a megállapítása (4. táblázat) után fontos a pótlás, a kezelés mielőbbi megkezdése. Elsőként, ha lehetséges, a kiváltó ok megszüntetése szükséges. Ezután a magnéziumbevitel növelése javasolt részint a táplálkozás/életmód megváltoztatása révén (dús magnéziumtartalmú ételek, zöldségek, magasabb magnéziumtartalmú ásványvizek preferenciája), részint pedig - és ez a fontosabb - magnéziumtartalmú gyógyszerek szedésével. ${ }^{1,2,4,5,29,30}$

A magnéziumkészítmények választéka igen széles: árban, minőségben, a magnéziumsót és a magnéziummennyiséget tekintve is. Összehasonlításuk nem könnyű, mert különböző magnéziumsókat tartalmaznak, gyakran két különböző magnéziumsó keverékét, amelyekből a felszabaduló magnéziumionok felszívódása és hasznosulása is eltérő. A magnézium felszívódása közismerten fokozódik, ha szerves savakkal kötött magnéziumvegyületeket (aszparaginsav, tejsav, citrát, orotsav stb.) alkalmaznak. ${ }^{29,30}$ A felszívódás azonban közel sem teljes (10-40\%), és sok más tényezőtől is függ: a szervezet magnézium-ellátottsága, a béltartalom fizikai és kémiai tulajdonságai, tranzitidő stb. ${ }^{29,30}$ A magnéziumot tartalmazó készítmények maguk is csökkenthetik más gyógyszerek (pl. tetraciklinek, digitálisz-glikozidok, bifoszfonátok) felszívódását, ezért ezen gyógyszerek és a magnéziumtabletták bevétele között legalább 3 óra eltelte javasolt. ${ }^{29}$ A magnéziumot $\mathrm{B}_{6}$-vitaminhoz kapcsolva javul a kation felszívódása. ${ }^{29,30}$ Más magnéziumkészítményekhez viszonyítva a magnézium-orotát biohasznosulása, szöveti dúsulása bizonyult a legjobbnak állatkísérletekben. ${ }^{31}$

A cardiovascularis betegségek (pl. krónikus systolés szívelégtelenség additív kezelése, strukturális szívbetegség nélkül, vagy stabil strukturális szívbetegség melletti szívritmuszavarok: pitvari vagy kamrai extrasystolék, pitvarfibrillációs epizódok stb.) per os magnéziumkezelésére napi $20 \mathrm{mmol}$ (480 mg) magnézium adása javasolt 7-10 napig, majd a telítő adag felére csökkentése, $10 \mathrm{mmol}$ (240 mg) magnézium/nap fenntartó adagra, vérszintkontroll mellett. ${ }^{3}$

Amennyiben a magnéziumadás akut, iv. terápiás indikációja áll fenn (pl. torsades des pointes multiform kamrai tachycardia, hosszú QT szindróma), akkor 1-2 g magnéziumszulfát iv. bolus 2-5 perces lassú injekciója vagy cseppinfúziója (2 g magnézium-szulfát $500 \mathrm{ml}$ fiziológiás konyhasóban), majd 3-20 mg/min fenntartó, infúziós pumpával végzett kezeléssel a klinikai állapot javulásáig. 
A következő kérdés a „magnéziumlaikusoktól” általában az, hogy magnéziumpótlásra, tartós szedésre melyik készítményt válasszák, vagy javasolják gyógyszerészeik, orvosaik.

\section{Érvek a magnézium-orotát (Magnerot)- választás/kezelés mellett}

A magnézium-orotát-dihidrát kettős, aktív, életfontosságú, additív hatású hatóanyaga (orotsav + magnézium: 1 tabletta $500 \mathrm{mg}, 32,8 \mathrm{mg}=1,5$ $\mathrm{mmol} \mathrm{Mg}$ ) révén különleges helyet foglal el a készítmények között. Az orotsav (a pirimidin-bioszintézis intermedierje, régen $\mathrm{B}_{13}$-vitaminnak is hívták) biokémiai/élettani szerepénél fogva nemcsak kardioprotektív hatású, hanem elősegíti a magnéziumionoknak az intracelluláris térbe való áramlását és fixációját. Így ischaemia esetén a fontos ATP-magnézium kötések rendelkezésre állnak. ${ }^{29,30}$ Experimentális vizsgálatok is igazolták, hogy a vizsgált magnéziumkészítmények közül enterális felszívódást követően a magnézium-orotát dúsul fel legjobban a különböző szövetekben (máj, vese, szív, tüdő). ${ }^{31,32}$

A magnézium-orotát hatékonyságát vizsgálták legszélesebb körűen az orális magnéziumkészítmények közül állatkísérletekben ${ }^{31,32}$ és klinikai vizsgálatokban ${ }^{33,34,35,36}$ egyaránt. Az experimentális vizsgálatok a magnézium-orotát érvédő, érszűkületcsökkentő, a szívizomműködés optimalizációjára utaló, a szívizom-ischaemia mérséklődését, antiaritmiás hatását igazolták, összességében kardioprotektív jellegű tulajdonságokkal, különösen kóros állapotokban. A placebokontrollált, randomizált vizsgálatok a magnézium-orotát hatékonyságát igazolták cardiovascularis megbetegedések megelőzésében és kezelésében (szívritmuszavarok, hypertonia, szívelégtelenség, angina pectoris, atherosclerosis stb. $)^{1,2,5,29,30,33,34,35,36}$ Ezenkívül additív szerként fontos a T2DM kialakulásának és progressziójának a csökkentésére, valamint extracardialis betegségek kezelésére is (preeclampsia, migrén, a görcskészség fokozódása stb.). ${ }^{1,2,5,11,15,21,22,25,26}$

Âr/érték arány: bár a magnézium-orotát kettős aktív hatóanyag-tartalmánál fogva magasabb árkategóriába tartozik, elismert klinikai hatékonysága miatt magas terápiás értéket képvisel. ${ }^{29,30,33,35}$
Káros mellékhatástól mentes: biztonságosan alkalmazható terhesség és szoptatás alatt is. Ritkán hasmenést, híg székletet okozhat, különösen magnézium-tartalmú savkötők együttes szedésekor. Jól kombinálható bármely más gyógyszerrel. 29,30,33,35,36

Az előzőek alapján a magnézium-orotát kiemelkedő biokémiai, élettani additív hatásai révén a jelenlegi magnéziumkészítmények közül elsőként javasolható az elterjedt magnéziumhiányos állapotok vagy cardiovascularis betegségek, ${ }^{1,25,29,30}$ a T2DM megelőzésére, mindennapos kezelésé$\mathrm{re}^{1,2,5,21,22,24,25,26}$ egyaránt.

A nyugati típusú táplálkozású világban, így itthon is elterjedt, látens magnéziumhiány életminőséget és élettartamot is befolyásoló hátrányai egyre inkább tudatosulnak nemcsak az orvosokban, hanem az egészséges életre törekvő lakosságban is. Ezért a lakosság egyre nagyobb része fordul a táplálékláncból, szervezetből hiányzó fontos biofaktor, a magnézium gyógyszeres pótlása felé. A magnézium cardiovascularis, metabolikus protektív hatásain felül erősíti a szervezet immunitását, támogatja a biokémiai és élettani genetikai variációk stabilitását, szerepe lehet az onkológiai megelőzésben és az öregedéshez vezető folyamatok lassításában. ${ }^{1,2,5,7}$ Az újabb magnéziumkutatással kapcsolatos ismeretek elterjedése miatt a magnézium már nem viseli az „elfelejtett”, sokkal inkább a „megértett”, de még nem teljesen megismert jelzőt. ${ }^{1,2,5,11}$

Közlésre érkezett: 2018. szeptember 3.

Közlésre elfogadva: 2018. november 14.

A szerzö levelezési címe

Prof. dr. Borbola József

Gottsegen György Országos Kardiológiai Intézet, Felnőttkardiológiai Osztály

1450 Budapest, Pf. 88.

E-mail: borbola@kardio.hu 


\section{rodalom}

1. Baaii JHF, Hoenderop JGH, Bindels RJM: Magnesium in man: implications for health and disease. Physiol Rev 2015; 95: 2-45. doi:10.1152/physrev. 00012.2014

2. Rosanoff A, Wolf Fl: Magnesium in Health and Disease. Magnes Res 2016; 29:55-59.

3. Borbola J: Fókuszban az antiaritmiás magnézium kezelés. Card Hung 2016; 46: 34-44.

4. Borbola J: Fókuszban a magnézium-orotát kezelés (1). A magnézium élettani jelentősége. Háziorv Továbbképzö Szemle 2018; 23: N1-N6.

5. Gröber U, Schmidt J, Kisters K: Magnesium in prevention and therapy. Nutrients 2015; 7: 8199-8226. doi:10.3390/nu7095388

6. Várkonyi T, Zajkás G, Kiss Z: A magnézium szerepe az emberi szervezetben (in: Fazekas T, Selmeczi B, Stefanovits P [eds.]: A Magnézium. Akadémiai Kiadó, Budapest, 1992.) pp. 137-178.

7. Guasch-Ferré M, Bullo M, Estruch R, Corella D, Martinez-Gonzáles MA, Ros E., et al.: Dietary magnesium intake is inversely associated with mortality in adults at high cardiovascular disease risk. J Nutr 2014; 144: 55-60. doi:10.3945/jn. 113.183012

8. Borbola J: Fókuszban a magnézium-orotát (2). A kardiovaszkuláris magnéziumkezelés fontossága: út az egészséges, hosszú élet felé. Háziorv Továbbképző Szemle 2018; 23: N7-N11.

9. DelGobbo LVC, Elin RJ, Poirier P, Engeland GM: Serum magnesium: a biomarker of cardiovascular risk revisited. Magnes Res 2012; 20: 1-5. doi:10.1684/mrh.2012.0309

10. Rylander R, Remer T, Berkemayer S, Vormann J: Acid-base status affects renal magnesium losses in healthy, elderly persons. J Nutr 2006; 136: 2374-2377. doi: $10.1093 / \mathrm{j} / 136.9 .2374$

11. Ehrlich B, Barbagallo M, Classen HG, Guerrero-Romero F, Mooren FC, Rodrigez-Moran $\mathrm{M}$, et al.: Significance of magnesium in insulin resistance, metabolic syndrome, and diabetes-recommendations of the Association of Magnesium Research V. Trace Elements and Electrolytes 2017; 34: 124-129. doi:10.5414/TEX01473

12. Rigó J, Fazekas T, Sonkodi S, Janka Z, Kovács L, Lonovics J, et al:: A magnézium kórélettana és klinikuma (in: Fazekas T, Selmeczi B, Stefanits P [eds.]: A Magnézium. Akadémiai Kiadó, Budapest, 1992.) pp. 179-260.

13. Liebscher DH, Liebscher DE: About the misdiagnosis of magnesium deficiency. J Am Coll Nutr 2004; 23: 730S-7315. doi:10.1080/07315724.2004.10719416

14. Costello RB, Elin RJ, Rosanoff A, Wallace TC, Guerrero-Romero F, Hruy $A$, et al: Perspective: the case for an evidence-based reference interval for serum magnesium: the time has come. Adv Nutr 2016; 7: 977-993. doi:10.3945/an. 116.012765

15. Kupetzky-Rincon EA, Vitto J: Magnesium novel applications in cardiovascular disease: a review of the literature. Ann Nutr Metab 2012; 61: 102-110. doi:10.1159/000339380

16. Kieboom BCT, Niemeijer MN, Leening MJG, Borg ME, Franco OH, Deckers $J W$, et al: Serum magnesium and the risk of death from coronary heart disease and sudden cardiac death. J Am Heart Assoc 2016; 5: e002707. doi:10.1161/JAHA. 115.002707

17. Kim DJ, Xun P, Liu K, Loria C, Yokota K, Jacobs DR, et al.: Magnesium intake in relation to systemic inflammation, insulin resistance, and the incidence of diabetes. Diabetes Care 2010; 33: 2604-2610. doi:10.2337/dc10-0994

18. Everett $C$, King DE: Serum magnesium and the development of diabetes. Nutrition 2006; 22: 679-685. doi:10.1016/j.nut.2006.04.001

19. Pham PC, Pham PM, Pham PA, Pham SV, Pham HV, Miller JM, et al.: Lower serum magnesium levels are associated with more rapid decline of renal function in patients with diabetes mellitus type 2. Clin Nephrol 2005; 63: 429-436. doi:10.5414/CNP63429
20. Pham PC, Pham PM, Pham SV, Miller JM, Pham PT: Hypomagnesemia in patients with type 2 diabetes. Clin J Am Soc Nephrol 2007; 2: 366-373. doi: $10.2215 / \mathrm{CJN} .02960906$

21. Larsson SC, Wolk A: Magnesium intake and risk of type 2 diabetes: a meta-analysis. I Intern Med 2007; 262: 208-214. doi:10.1111/j.1365-2796.2007.01840.x

22. Lopez-Ridaura R, Willett WC, Rimm EB, Liu S, Stampfer MJ, Hu FB, et al:: Magnesium intake and risk of type 2 diabetes in men and women. Diabetes Care 2004; 27: 134-140. doi:10.2337/diacare.27.1.134

23. Wang J, Peresville G, Olendzki BC, Wedick NM, Zhang Z, Merriam PA, et al.: Dietary magnesium intake improves insulin resistance among nondiabetic individuals with metabolic syndrome participating in a dietary trial. Nutrients 2013;5:3910-3919. doi:10.3390/nu5103910

24. Song Y, Manson JE, Buring JE, Liu S: Dietary magnesium intake in relation to plasma insulin levels and risk of type 2 diabetes in women. Diabetes Care 2004; 27: 59-65. doi:10.2337/diacare.27.1.59

25. Guerrero-Romero F, Rascón-Pancheco RA, Rodrigez-Morán M, Pena JE, Wacher $\mathrm{N}$, et al: Hypomagnesaemia and risk for metabolic glucose disorders: a 10-year follow-up study. Eur J Clin Invest 2008; 38: 389-396. doi:10.1111/j.1365-2362.2008.01957.x

26. Guerrero-Romero F, Simental-Mendia LE, Hernandez-Ronquillo G, RodriguezMoran M: Oral magnesium supplementation improves glycaemic status in subjects with prediabetes and hypomagnesaemia: a double-blind placebo-controlled randomized trial. Diabetes Metab 2015; 41: 202-207. doi:10.1016/j.diabet.2015.03.010

27. Hruby A, Meigs JB, O'Donnell CJ, Jacques PF, McKeown NM: Higher magnesium intake reduces risk of impaired glucose and insulin metabolism and progression from prediabetes to diabetes in middle-aged americans. Diabetes Care 2014; 37: 419-427. doi:10.2337/dc13-1397

28. Wu J, Xun P, Tang $Q$ and He Ka: Circulating magnesium levels and incidence of coronary heart disease, hypertension and type 2 diabetes: a meta-analysis of prospective cohort studies. Nutrition J. 2017; 16: 1-13. doi:10.1186/s12937-017-0280-3

29. Pogátsa G: Magnéziumpótlás Magnerottal. Háziorvos Továbbképzö Szemle 2015; 20: 126-133.

30. Borbola J: Az ideális per os magnézium-készitmény megválasztásának orvosi szempontjai. Háziorv Továbbképző Szemle 2018; 23: 371-375.

31. Moisa C, Vicas LG, Ganea M, Levei EA, Cadar 0 and Berce C: Murine studies regarding the tissue intake of different magnesium compounds. Farmacia 2018; 66: 176-180.

32. Mirica SN, Duicu OM, Trancota SL, Fira-Mladinescu O, Angoulvant D, Munteau DM: Magnesium orotate elicits acute cardioprotection at reperfusion in isolated and in vivo rat hearts. Can J Phys Pharm 2013; 91: 108-115. doi:10.1139/cjpp-2012-0216

33. Schmidt J: Magnesium orotat. Deutsche Apothekar Zeitung 1998; 138: 66-70.

34. Stepura $O B$, Martynow Al: Magnesium orotate in severe congestive heart failure (MATCH). Int I Cardiol 2009; 134: 145-147. doi:10.1016/j.jijcard.2009.01.047

35. Rosenfeld FL: Editorial: Metabolic supplementation with orotic acid and magnesium orotate. Cardiovasc Drugs and Therapy 1998; 12: 147-152. doi:10.1023/A:1007732131887

36. Golf SW, Bender S, Gróttner I. On the significance of magnesium in extreme physical stress. Cardiovasc Drugs Therap 1998; 12: 197-202. doi:10.1023/A:1007708918683 